\title{
ANALYSIS OF TREASURER ACCEPTANCE TO ACCRUAL BASE IMPLEMENTATION BASED ON GOVERNMENT REGULATION NO. 71 YEAR 2010: CASE STUDY IN OPEN UNIVERSITY
}

\author{
Olivia Idrus ${ }^{1 *}$ and Noorina Hartati ${ }^{2}$ \\ ${ }^{1,2}$ Universitas Terbuka, Indonesia
}

\begin{abstract}
For determining the total income amount and load precisely in the same period, there are two available choices which are able to be the recording basis by accountants which are the cash basis and accrual basis. A study result implemented by the IFAC Public Sector Committee (2002) stated that accrual based reporting is useful in evaluating government performance related with costs of service, efficiency, and reaching goals. With accrual based reporting, users are able to identify the government's financial position and its change, how the government funds its activities corresponding with the funding ability, so the real government capacity is able to be measured, In 2010, the accrual based Government Accounting Standard has finished being arranged by the Government Accounting Standard Committee and determined as a Government Regulation in Government Regulation Number 71 Year 2010. The implementations of the regulation are, Financial Reports of Central and Regional Governments are gradually motivated for applying accrual based accounting. The Open University as a Public University is not excluded from the Government Regulation Number 71 Year 2010. The transition of the recording method from the cash basis to the accrual basis of course will impact several matters. Because of that the researcher is interested for observing the acceptance attitude of treasurers in the Open University environment, in the Central Open University and the Long Distance Learning Program Unit-Open University which disperse in 39 Long Distance Learning Program Units-Open University, as a cause of the accounting basis transition. This acceptance attitude will observe the following aspects: Personal Comfort, Change as a Challenge, Employment Uncertainty, Job Results, Control of Employment, Freedom in Employment, and Satisfaction.

Keywords: Acceptance Attitude, Change as Challenge, Control of Employment, Job Results, Personal Comfort, Satisfaction
\end{abstract}

\section{INTRODUCTION}

The accounting definition according to the American Institute of Certified Public Accountants (AICPA) in Baridwan (2004) is as the following:

Accounting is a service activity. Its function is to provide quantitative data, especially which has finance characteristics, from an economic business unit which is able to be used in making economic decisions in choosing alternatives from a situation.

* Corresponding author. Email address: olivia@ecampus.ut.ac.id 
When an accounting division of a company will compose a financial report, they realize that the bookkeeping period of a company which will be reported can be divided to several periods. By using this accounting period concept, accountants have to be careful and be precise as possible in determining the income amount and charges which has to be reported in the financial report. For determining the precise income amount and charges in the right period, there are two available choices which are able to be a recording basis by accountants, which are the cash basis and accrual basis (Hery, 2014).

If the recording (accounting) basis that is used is the cash basis, the income and charges will be reported in the income statement in the period where the cash is obtained (income) or the cash is paid (charges). So, it is able to be concluded that income and charge transactions which will be reported in the income statement are transactions that involve cash inflows (income) or cash outflows (charges). The net income amount or net loss produced from the difference between income and charges, will reflect the net amount of cash produced (net income) or amount of cash spent (net loss) (Hery, 2014).

Meanwhile if the recording (accounting) basis used is the accrual basis, the income and charges will be reported in the income statement in the period where the income and charges occur, without paying attention to cash inflows or cash outflows. With the accrual basis, the charges which are related with creating income have to be reported in the same period where the income is also recognized. The accounting concept which supports the reporting of income and charges which are related in the same period is known as the matching concept (Hery, 2014). The transition of the accounting basis from a cash basis to accrual is of course a difficult situation, because essentially both basis have strengths and weaknesses. Yet government regulations influence the use of those accounting basis.

One of the study results implemented by the IFAC Public Sector Committee (2002) stated that accrual basis reporting is useful in evaluating government performance related with service costs, efficiency, and goal attainment. With accrual basis reporting, users can identify the government's financial position and its change, how the government funds its activities in corresponding with its financial ability so the real capacity is able to be measured. Accrual basis government accounting also makes it possible for the government to identify opportunities in using future resources and creating a good management of the resources (The Indonesian Budget Analysis Bureau of Budget and Implementation).

Act Number 17 Year 2003 about National Finance Article 36 clause (1) and Year 2004 Act about National Treasury Article 70 clause (2) entrusts the government for applying accrual based accounting in composing and presenting the national income and spending report at the latest in Budget Year 2008. Since the rise of the Act package in the National Finance field, the government has prepared steps for applying accrual basis accounting (The Indonesian Budget Analysis Bureau of Budget and Implementation).

In 2005 the government published Government Regulation Number 24 Year 2005 about the Government Accounting Standard. The regulation manages cash towards accrual basis accounting and is a transition Government Regulation because the Act of National Finance and National Treasury entrusts the recognition and measure of accrual basis income and spending. In 2010 the accrual basis Government Accounting Standard was composed by the 


\section{ANALYSIS OF TREASURER ACCEPTANCE TO ACCRUAL BASE IMPLEMENTATION BASED ON GOVERNMENT REGULATION NO. 71 YEAR 2010: CASE STUDY IN OPEN UNIVERSITY}

Government Accounting Standard Committee and set as a Government Regulation in Government Regulation Number 71 Year 2010. The implementation of that regulation, Central and Regional Government Financial Reports are gradually pushed to apply accrual basis accounting. At the latest in 2015 all financial reports in the central and regions are expected to apply the accrual basis Government Accounting Standard (Armada, 2013). The Open University as one of the Public Universities is not excluded from the Government Regulation Number 71 Year 2010. This recording method transition of course will impact several matters. Because of that the researcher is interested to observe the acceptance attitude of Treasurers in the Open University environment, in the Central Open University and in the Long Distance Learning Program Unit-Open University which disperse in 39 Long Distance Learning Program Units-Open University, as a cause of the transition of the accounting basis.

\section{LITERATURE REVIEW}

\section{Accrual Basis Accounting Recording}

Generally accounting recording is based on two systems which are cash basis and accrual basis. The cash basis according to the Government Standard Accounting Study is an accounting basis which recognizes the influence of transactions and other occurrences when cash or equivalent is accepted or paid. In the cash basis, transactions are recognized when cash is accepted or paid without looking when the transaction appeared/occurred. While the Accrual Basis is an accounting basis which recognizes transaction influence and other occurrences when the transaction and occurrence takes place, without noticing when the cash or equivalent is accepted or paid. In the accrual basis, transactions are recognized when it appears/occurs without noticing when the cash/equivalent is accepted/paid (Rahayu, 2015).

This accounting with an accrual basis is considered better than the cash basis, because accrual basis accounting is believed to be able to produce a more trustworthy financial report, more accurate, comprehensive, and relevant for making decisions of economics, social, and political. The application of the accrual basis in public sector accounting is basically for knowing the cost amount needed for producing public service and determining the service price which is charged to the public (Armada, 2013).

\section{Open University Finance Management}

The finance management in the Open University refers to Minister of Finance Regulation Number 268/KMK.05/2011 dated August 162011 about the Application of Open University in the National Ministry as a government institution which applies Public Service Body finance management.

Based on National Education Minister Resolution No.123/O/2004 and Open University Statute based on National Education Minister Regulation Number 23 year 2007, the Public Service Body officials consist of the head of the Public Service Body which are the Rector, the Finance Management Officials which are the $2^{\text {nd }}$ Assistant Rector and Head of the Finance Affairs Administration Bureau and other technical officials which are the $1^{\text {st }}, 3^{\text {rd }}$, and $4^{\text {th }}$ Assistant Rectors, the Deans, Master Program Director, the Institution Heads, the Head of Academic Planning and Monitoring Administration Bureau, The Center Heads/Technical Implementation Units and the Heads of the Long 
Distance Learning Program Units (Finance Affairs Administration Bureau Open University,2015).

Technically, the staff which have direct involvement in the acquisition, liquidation, and responsibility of the budget in the Central Open University and the Long Distance Learning Program Units- Open University cover the Acquisition Treasurer and Expenses Treasurer (in the University Level) and Assistant Expenses Treasurer in the Central Open University units and all Long Distance Learning Program Units- Open University in Indonesia.

\section{Acceptance Attitude}

Attitude is initially defined as a requirement for an action emersion. That concept then develops wider and is used to illustrate a specific or general intention, related with control to response in certain situations (Zaim Elmubarok, 2009). Howard Kendler (Syamsu Yusuf, 2006: stated that attitude is a tendency to approach and avoid and implementing something, positively or negatively, to an institution, event, idea or concept.

This research uses an instrument developed by Anjulo Arabinda Tripathy (2000) which covers several factors, which are:

\section{a. Personal Comfort}

According to Kolcaba (2003) comfort is a situation that fulfills human basic needs which are individual and holistic in character. Comfort is a comprehensive assessment of a person to the environment. The human assessment to conditions in the environment is based on inputs which enter their selves through six senses through nerves, which is then processed by the brain to be assessed. Then the brain will provide relative assessment if the condition is comfortable or not. In this matter what is involved is not only biological physical problems, but also feelings (Satwiko, 2009).

The comfort level of a person is very dependent on the person which experiences the situation (Sanders \& McCormick, 1993). We are not able to know the comfort level felt by other persons directly or with observation without asking directly to persons about how comfortable they are. Because of that the comfort perception of every person is different between one individual and another.

b. Transition as a Challenge

Lippit (1973) defines transition as something planned or unplanned to the status quo in the individual, situation or process and in planning expected transition, is planned by individuals, groups, organizations or social systems which influence directly about status quo, other organizations or other situations.

In implementing transition, there are several obstacles faced, which are the unwillingness or inability for changing old attitude and behavior which have been habits and the individual tendency to be provided freedom to return to the behavior pattern which is already a habit.

\section{c. Employment Uncertainty}

Uncertainty according to Mishel (in Kang, 2002) is able to be defined as a situation that involves cognition where the subject is not able to determine values in an occurrence or object and is not able to predict results accurately because of a lack of signal, and unclear and not exact information. Uncertainty becomes greater with the increase of disturbances to the identity aspect of a person's life. 


\section{ANALYSIS OF TREASURER ACCEPTANCE TO ACCRUAL BASE IMPLEMENTATION BASED ON GOVERNMENT REGULATION NO. 71 YEAR 2010: CASE STUDY IN OPEN UNIVERSITY}

According to theories, uncertainty develops from several antecedent variables (structure provision, stimulus frame, and cognitive capacity) which are mediated with personality and primary assessment characteristics. The mediators between uncertainty and results from uncertainty covers: optimism (Christman, 1990); expectation (Hilton, 1994); dominance (Mishel, 1991); and information searching (Rosenbaum in Albertsen, 2009).

d. Employment Results

According to the International Labor Organization (ILO) productivity is an arithmetic comparison between the produced amount and the amount of every resource used in the production period. The resources can be in the forms of soil; raw materials and adjuvants; factories, machines and instruments; and labor.

The productivity concept basically is able to be observed from two dimensions, which are the atindividual dimension and organization dimension (Kusnendi, 2003). From the individual dimension, productivity means a view that life quality today has to be better than yesterday and tomorrow has to be better than today. While from the organization dimension, the productivity concept is the effort to utilize input sources to obtain an optimal output.

\section{e. Control of Employment}

Locus of control according to Spector (Munir \& Sajid, 2010) is a reflection from a tendency of an individual to believe that he or she controls the events that occur in his or her life (internal) or control of the events that occur in his or her life are from other matters, such as authority of others (external). As for the definition of locus of control according to Rotter (Suwarsi \& Budianti, 2009) is a matter which is certain to provide contribution to a person's performance quality, which is the early response as the base from responses done later. So this locus of control is a person's perception to his or her success or failure in doing several activities which are caused by self-control or control outside their selves.

So there are 2 locus of control dimensions, which are internal and external (Rotter, 1990) In internal locus of control, people believe that results from their behavior depend on their self-assessment or personal characteristics. Contrarily external locus of control refers to how far a person expects that their strengthening or work results are functions from chance, luck, or fate are under the control of the strength of other persons.

f. Freedom in Employment

Zhou and Shalley, (2008) stated that job autonomy in here refers to the freedom and independence that people do, have tasks in determining how to implement their tasks. According to Elsass and Veiga (1997) in Susanti Saragih (2011), job autonomy allows individuals to limit their employment load of stress which they may face and in this matter an employee is able to freely choose his or her tasks or allow individuals to limit tasks so employment stress does not occur, so it reduces the feelings that threaten and motivates positive behavior. According to Gellatly and Irving (2001), Langfred and Moye (2004) in Susanti Saragih (2011) job autonomy is able to increase performance because employees a with high job autonomy will see that he or she is trusted to implement the job. 
According to Hackman and Oldham (1975) in Susanti Saragih (2011) job autonomy is defined as how far employment provides substantial freedom, independence, and discretion for individuals in scheduling jobs and in determining the procedure which needs to be used in implementing them. Where it has primary characteristics such as, expertise variation, task identity, task significance and feedback from employment.

g. Satisfaction

Job satisfaction is defined by Robbins and Judge (2008) as a positive feeling about a person's job which is a result of the characteristic evaluation. Basically job satisfaction depends on what an employee desires from his or her job and what they obtain (Moorse, 2002). So job satisfaction is an individual matter. Every individual has different levels of satisfaction corresponding with their value systems. The more job aspects which are corresponding with the desires of the individual the higher the satisfaction level felt.

\section{RESEARCH METHOD}

\section{Research design}

This research is a descriptive research with a survey design. The purpose of a survey design is to see how far has the acceptance attitude of Open University treasurers to the accrual basis implementation has come. This survey design uses questionnaires which are sent online to all treasurers in the Central Open University and in the Long Distance Learning Program Units-Open University totaling 58 treasurers and interviews in 5 (five) Long Distance Learning Program Units-Open University which are selected based on the obtained budget which are Large Budget (Long Distance Learning Program Unit-Open University Purwokerto and Long Distance Learning Program UnitOpen University Jakarta) Medium Budget (Pangkal Pinang) and Small Budget ((Long Distance Learning Program Unit-Open University Gorontalo and Long Distance Learning Program Unit-Open University Bogor).

\section{Population and sample}

The population of this research are all Assistant Expense Treasurers in the Central Open University and in the Long Distance Learning Program UnitsOpen University. The number of Assistant Expense Treasurers in the Central Open University units are as many as 18 persons while the Assistant Expense Treasurers in the Long Distance Learning Program Units-Open University are as many as 41 persons. So the total sample in this research amount at 59 persons.

\section{RESULTS AND DISCUSSION}

\section{Descriptive Statistics}

Generally, most respondents feel that they feel comfortable about the presence of this accounting principle transition. Respondents also feel that this change is a challenge for them to be more responsible and committed to work. In the matter of employment uncertainty, most respondents feel the presence of a better job safety. Other than that this accounting principle change is also considered to be able to increase their job productivity and does not make then lose control of their employment. Nevertheless, some respondents feel that this accounting principle transition does not heighten their freedom in decision making, even though it heightens their expectations in reaching job satisfaction. 


\section{Stages and Test Results}

Tests are implemented with the Structural Equation Modelling, which is by using the maximum likelihood estimation.

\section{Aggregate Model Compatibility}

The aggregate model compatibility test is implemented based on the Goodness-of-fit Index (GFI) statistic from the LISREL output (Wijayanto, 2008). The compatibility test of all GFI indicators are able to be seen in the following table 1:

Table 1 Aggregate Model Compatibility Test Results

\begin{tabular}{|c|c|c|c|}
\hline $\begin{array}{l}\text { Models } \\
\text { Criteria for } \\
\text { Suitability }\end{array}$ & Compatibility Level Indicator & $\begin{array}{l}\text { Model } \\
\text { Estimation } \\
\text { Results } \\
\end{array}$ & $\begin{array}{c}\text { Level of } \\
\text { Suitability } \\
\text { Model }\end{array}$ \\
\hline $\begin{array}{l}\text { RMSEA } \\
\text { P (close fit) }\end{array}$ & $\begin{array}{l}\text { RMSEA }<0,08 \\
P<0.05\end{array}$ & $\begin{array}{l}0.076 \\
0.15\end{array}$ & Good Fit \\
\hline ECVI & $\begin{array}{l}\text { Smaller values of Independence and } \\
\text { closer to the Saturated Model }\end{array}$ & $\begin{array}{l}\mathrm{M}^{*}=3.24 \\
\mathrm{~S}^{* *}=4.14 \\
\mathrm{I}^{* * *}=21.35\end{array}$ & Good Fit \\
\hline AIC & $\begin{array}{l}\text { Smaller values of Independence and } \\
\text { closer to the Saturated Model }\end{array}$ & $\begin{array}{l}\mathrm{M}^{*}=188.03 \\
\mathrm{~S}^{* *}=240.00 \\
\mathrm{I}^{* * *}=1238.10\end{array}$ & Good Fit \\
\hline CAIC & $\begin{array}{l}\text { Smaller values of Independence and } \\
\text { closer to the Saturated Model }\end{array}$ & $\begin{array}{l}\mathrm{M}^{*}=317.29 \\
\mathrm{~S}^{* *}=609.30 \\
\mathrm{I}^{* * * *}=1284.26\end{array}$ & Good Fit \\
\hline NFI & $\mathrm{NFI}>0.90$ & 0.91 & Good Fit \\
\hline NNFI & $\mathrm{NNFI}>90$ & 0.96 & Good Fit \\
\hline CFI & $\mathrm{CFI}>0.90$ & 0.97 & Good Fit \\
\hline IFI & IFI $>0.90$ & 0.97 & Good Fit \\
\hline RFI & $\mathrm{RFI}>0.90$ & 0.87 & Marginal Fit \\
\hline RMR & Standardized RMR $<0.05$ & 0.047 & Good Fit \\
\hline GFI & $\begin{array}{l}\text { GFI }>0.90, \text { good fit } ; 0.90<\mathrm{GFI}> \\
0.80, \text { marginal fit }\end{array}$ & 0.81 & Marginal Fit \\
\hline
\end{tabular}

From table 1.1 it is able to be seen that there are 2 GOF (Goodness-of-fit) measures which show poor compatibility from 13 GOF measures which show good compatibility. Based on the analysis results it is able to be concluded that the model is good or good fit.

\section{Measurement Model Compatibility}

By testing measurement model compatibility, there needs to be an evaluation to validity and reliability from the measurement model (Wijayanto, 2006). 


\section{Validity Test}

The validity test basis consists of 7 variables, which are: (1) Personal Comfort, (2) Transition as a Challenge, (3) Employment Uncertainty (4) Employment Results, (5) Control of Employment, (6) Freedom in Employment, and (7) Satisfaction, The obtained result shows that there are 2 variables which need to be eliminated because they have $\mathrm{SLF} \leq 0.5$ and $\mathrm{t}$-value $\leq 1.96$ which are Variable 3 (Employment Uncertainty and Variable 6 (Freedom in Employment).

\section{$\underline{\text { Reliability Test }}$}

For testing consistency from the bundles of questions in the questionnaire, the reliability test is implemented, by calculating the construct reliability and variance extracted from each observed variable (Wijayanto, 2006).

The construct reliability and variance extracted calculation results for 5 variables are presented in the following table 2:

Table 2 Construct Reliability and Variance Extracted Values of each Latent

\begin{tabular}{|c|c|c|c|c|}
\hline \multicolumn{5}{|c|}{ Variable } \\
\hline No & Variable & $\begin{array}{l}\text { Construct } \\
\text { Reliability }\end{array}$ & $\begin{array}{l}\text { Variance } \\
\text { Extracted }\end{array}$ & Conclusion \\
\hline 1. & $\begin{array}{ll}\begin{array}{l}\text { Personal } \\
\text { (comfortable) }\end{array} & \text { comfort }\end{array}$ & 0,85 & 0,54 & Good \\
\hline 2. & $\begin{array}{l}\text { Transition as a challenge } \\
\text { (challenge) }\end{array}$ & 0,83 & 0,62 & Good \\
\hline 3. & $\begin{array}{l}\text { Employment } \quad \text { Results } \\
\text { (perform) }\end{array}$ & 0,99 & 0,99 & Good \\
\hline 4. & $\begin{array}{l}\text { Control of Employment } \\
\text { (control) }\end{array}$ & 0,87 & 0,63 & Good \\
\hline 5. & Satisfaction (satisfied) & 0,99 & 0,99 & Good \\
\hline
\end{tabular}

From the Construct Reliability and Variance Extracted calculation results of those 5 variables it is able to be seen that all have a Construct Reliability above $0.70(\mathrm{CR} \geq 0.70)$ and Variance Extracted above $0.5(\mathrm{VE} \geq 0.50)$. This shows that all indicators in those variables are reliable.

\section{Structural Model Compatibility}

This structural model analysis is implemented to test the hypothesis which shows the presence of causal relations or influence between one variable and other variables (Wijayanto, 2008).

Based on analysis results of this structural model, as a whole the t value and coefficient estimation from the 5 hypotheses which are tested in this research are concluded with results in the following table 3: 
ANALYSIS OF TREASURER ACCEPTANCE TO ACCRUAL BASE

IMPLEMENTATION BASED ON GOVERNMENT REGULATION NO. 71 YEAR

2010: CASE STUDY IN OPEN UNIVERSITY

Table 3 T-value Worth For Each Hypothesis

\begin{tabular}{cllccc}
\hline Hypothesis & \multicolumn{1}{c}{ Relation } & Estimation & $\begin{array}{c}\text { T- } \\
\text { Value }\end{array}$ & Conclusion \\
\hline $\mathbf{H 1}$ & $\begin{array}{l}\text { Comfortable } \\
\text { Acceptable }\end{array}$ & $\rightarrow$ & -1.43 & -1.48 & Not Significant \\
$\mathbf{H 2}$ & $\begin{array}{l}\text { Challenge } \\
\text { Acceptable }\end{array}$ & $\rightarrow$ & 1.37 & 1.45 & Not Significant \\
$\mathbf{H 3}$ & $\begin{array}{l}\text { Perform } \\
\text { Acceptable } \\
\text { Control } \\
\text { Acceptable } \\
\text { Satisfied } \\
\text { Acceptable }\end{array}$ & $\rightarrow$ & -0.07 & -0.30 & Not Significant \\
H5 & $\rightarrow-0.53$ & 1.46 & Not Significant \\
\hline
\end{tabular}

\section{CONCLUSION AND SUGGESTIONS Conclusion}

Based on the analysis results of 59 Assistant Expense Treasurers in the Central Open University and in the Long Distance Learning Program UnitsOpen University the following matters are concluded:

1. The personal comfort factor has a negative but insignificant relation ( $t-$ value $=-1.48$; estimation coefficient $=-1.43$ ), to treasurer acceptance attitude of the implementation of a new regulation, which is accrual basis in their finance reporting. This means that the more comfortable treasurers are with their jobs, the less they will accept a new regulation, in this matter the transition of the accounting recording system from the cash basis to the accrual basis.

2. The transition as a challenge factor, in this matter the presence of an increase of responsibility feelings, increase of commitment to employment and feeling the presence of progress in the workplace shows a t-value test result as large as 1.45 and estimation coefficient of 1.37. This shows the presence of a positive relation but not significant, where the more treasurers feel challenged about their jobs, the more they want to accept a new regulation.

3. The test results of employment results with the treasurer acceptance attitude show a coefficient estimation value as large as -0.07 and a t-value as large as-0.30. This value shows the presence of a negative relation but not significant, which means that the better treasurers work, the more they want to accept the new accrual basis regulation.

4. The test results of control of employment with the treasurer acceptance attitude shows that control of employment has a positive but not significant relation to treasurer acceptance attitude of a new regulation implementation. The coefficient estimation value as large as -0.53 and a t-value as large as 1.46 in the hypothesis show that the more that treasurers do not have control of their employment, the more they will accept a new regulation.

5. The analysis of treasurer satisfaction levels to their acceptance attitude show a coefficient estimation value as large as -0.56 and a t-value as large as 1.97. The presence of this negative and significant relation means that the more treasurers feel satisfied with their employment, the more that they do not accept a new regulation, in this matter the transition of accounting recording from a cash basis to an accrual basis. 
6. Based on the analysis results it is able to be concluded that only the satisfaction level has a significant influence to treasurer acceptance attitude to accounting recording system transition with the validity of Government Regulation no.71 Year 2010. This is able to be explained that some treasurers are already in their comfort zone so they feel some difficulty and hesitation to break out from that situation. The complication of accrual basis application compared with the cash basis is one of the primary factors. This is supported by the education backgrounds of some treasurers which are not from finance or economics. Some treasurers also have a reason of a lack of socialization about this new regulation implementation.

\section{Suggestions}

Based on the research conclusion above, the suggestions which are able

to be provided are as the following:

1. There are many treasurers who do not yet understand the accounting concept because they do not have an accounting education background. It is expected in selecting treasurers to choose staff with finance or accounting backgrounds.

2. There needs to be socialization about the applied new regulations.

3. Increase research samples, not just the Assistant Expense Treasurers but also the income treasurers, expense treasurers and related finance staff in the Central Open University.

\section{References}

Armada, Z. (2013). Pengelolaan Dan Pelaporan Keuangan Pemerintah Berdasarkan Pp No.71 Tahun 2010 Tentang Standar Akuntansi Pemerintahan. Downloaded from http://catatanpamong.blogspot.co.id/2013/09/pengelolaan-danpelaporan-keuangan.html on Monday/ March 72016 at 13.00

Baridwan, Z. (2004). Intermediate Accounting Edisi Delapan. Yogyakarta: BPFE FE UGM.

Dunia, F. A. (2008). Ikhtisar Lengkap Pengantar Akuntansi Edisi Ketiga. Depok: FE UI

Hadiwidjaja, R. D., \& Hendrian. (2014). Analisis Sikap Keberterimaan Bendahara atas Kepmendagri No. 55 Tahun 2008 Tentang Perbendaharaan Bagi Bendahara Pemerintah (Kasus di Tangerang Selatan). Prosiding Call for Papers \& Seminar Nasional “Asean Economic Community 2015: Lust or Trust?" ISBN: 978-60217225-2-7. Bandung: Indonesia Education University

Hery. (2014). Akuntansi Dasar 1 \& 2. Jakarta: Grasindo

Indonesian Budget Analysis and Implementation Bureau. Persiapan Penerapan Akuntansi Berbasis Akrual di Indonesia. Downloaded from http://www.dpr.go.id/doksetjen/dokumen/biro-apbnapbn-Persiapan-Penerapan-Akuntansi-Berbasis-Akrual-di-Indonesia1440121829.pdf on Tuesday/February 232016 at 13.25 
ANALYSIS OF TREASURER ACCEPTANCE TO ACCRUAL BASE IMPLEMENTATION BASED ON GOVERNMENT REGULATION NO. 71 YEAR 2010: CASE STUDY IN OPEN UNIVERSITY

Public Administration and Finance Bureau Open University (2015). Pedoman Pengelolaan Keuangan Unit Year 2015

Rahayu, Y. (2015). Reformasi Sistem Akuntansi Cash Basis Menuju Sistem Akutansi Accrual Basis, Ecodemica, Vol. III, No. 1 April 2015 (pages. 348-354). Downloaded from file:///C:/Users/UNIVER 1/AppData/Local/Temp/Reformasi_sistem_Ak untansi_Cash_B asis_me.pdf $\backslash$ on Monday/March 72016 at 14.00

Siregar, S. (2014). Metode Penelitian Kuantitatif, dilengkapi dengan Perbandingan Perhitungan Manual dan SPSS. Jakarta: Kencana

Wijanto, S. H. (2008). Structural Equation Modeling dengan Lisrel 8.8, Edisil. Yogyakarta. Graha Ilmu.

http://repository.usu.ac.id/bitstream/123456789/41143/4/Chapter\%20II.pdf

http://immadaunhijauselaluceria.blogspot.co.id/2011/11/teori-perubahanmenurut-para-ahli.html

library.binus.ac.id/eColls/.../2012-1-00409-PS\%20Bab2001.doc

http://eprints.uny.ac.id/8771/3/BAB\%202\%20-08404244003.pdf

http://library.binus.ac.id/eColls/eThesisdoc/Bab2/2012-2-01237MN\%20Bab2001.pdf

http://etheses.uin-malang.ac.id/2220/6/08410036_Bab_2.pdf

library.binus.ac.id/eColls/.../2012-2-00013-MN\%20Bab2001.doc

http://repository.usu.ac.id/bitstream/123456789/54733/4/Chapter\%20II.pdf http://eprints.uny.ac.id/7951/3/BAB\%202\%20-\%2008108241013.pdf 